\title{
Therapeutic effect of Moringa oleifera and Thymus vulgaris oils against hepatic coccidiosis in experimentally infected rabbits
}

\author{
Abu El Ezz, N.M.T., Aboelsoued, D.*, Hassan, S.E., Abdel Megeed, K.N. and El-Metenawy, T.M. \\ Department of Parasitology and Animal Diseases, National Research Centre, Dokki, Giza, Egypt \\ *Corresponding author e-mail: Dr.Dina.Aboelsoued@gmail.com \\ Received 6 May 2020; received in revised form 5 July 2020; accepted 6 July 2020
}

\begin{abstract}
The present study was conducted to detect the therapeutic effect of Moringa oleifera and Thymus vulgaris oils on hepatic coccidiosis in experimentally infected rabbits. Also, immunomodulatory effect of the two oils was detected. Twenty-four Newzealand rabbits were used in this study and divided into 4 groups; healthy rabbits, experimentally infected rabbits with Eimeria stiedae oocysts, and two infected treated groups (one with moringa $(200 \mathrm{mg} / \mathrm{kg}$ ) and the other with thyme (500 mg/kg) oils). The results showed highly significant reduction in oocysts shedding $(P<0.001$ and $P<0.05)$ in the two infected and treated rabbits than the infected non-treated rabbits in almost all days post infection (PI). Thyme oil was more potent and stopped oocysts shedding earlier at the day 34 PI compared to moringa oil at the day 41 PI. Microscopically, there was a damage in the oocysts shed by treated rabbits. Macroscopically, the livers of thyme oil treated rabbits showed more enhancement with protection percentage $75 \%$ than those treated with moringa oil in which protection percentage was 55\%. The highest titer of antibodies was detected in moringa oil treated rabbits. It was concluded that both moringa and thyme oils had an anti-coccidial effect with thyme oil superiority. So, thyme oil could be useful as an alternative product for the control of rabbit coccidiosis.
\end{abstract}

\section{INTRODUCTION}

Rabbit meat is a good source of high animal protein with low fat content (Nistor et al., 2013). From 2018, Egypt is considered the third largest producer of rabbit meat in the world following China and North Korea, where, Egyptian rabbit meat production was estimated by 62,143 tons (FAO, 2020). Coccidian parasites could affect this high commercial value of rabbits with direct and indirect losses as a result of acute illness, weight loss and high mortality and morbidity (El-Shahawi et al., 2012). Coccidiosis is a worldwide challenging disease of wild and domestic rabbits that affects different rabbit types (Chowdhury \& Fraser, 2008; Yin et al., 2016). In Egypt, Rabbit coccidiosis natural infection among rabbit herds reached 70\% (El-Shahawi et al., 2012). Its prevalence rate was found to be $26.87 \%$ in Iran (Tehrani et al. 2013), $11.5 \%$ in Kenya (Okumu et al., 2014) and $1.01 \%$ in India (Chacko et al., 2017). Two forms of coccidiosis were recognized in rabbits; intestinal and hepatic coccidiosis. Hepatic coccidiosis is a serious and lethal disease in rabbits caused by Eimeria stiedae (E. stiedae) (Sivajothi et al., 2016). Infection of the epithelial cells of the bile ducts occurs by ingestion of $E$. stiedae sporulated oocysts causing severe liver damage in rabbits (Oliveira et al., 2011; Abu El Ezz et $a l .$, 2012). Clinical symptoms of the disease are dullness, diarrhea or constipation, reduced food consumption, ascites, liver enlargement, icterus, a distended abdomen and nally death (Karaer, 2001). Young rabbits are more susceptible; however, infected adults can be carriers of the disease and act as a source of infection (Sivajothi et al., 2016). 
Traditional control strategies of the disease had counted mainly on chemoprophylaxis, which is expensive (Dalloul \& Lillehoj, 2005). Furthermore, the continuous use of anticoccidial drugs led to the emergence of drug resistance (El Banna et $a l ., 2016)$. In addition to concerns about drug resistance, there are also food safety and public health concerns about drug residues in animal products and so, this stimulates the researchers to find safer alternatives (Kheirabadi et al., 2014). Plant products could provide an alternative choice for coccidial control to which resistance has not yet developed (Abbas et al., 2012), reducing the farmer input costs and protect animal health (Abu El Ezz, 2005). Plant oils can be used as a replacement to current antiparasitic drugs (Anthony et al., 2005).

Previous studies had shown that moringa (Moringa oleifera; M. Oleifera) has many bioactive compounds including vitamins, essential amino acids, polyphenols, avonoids and phenolic acids (Leone et al., 2015). Many in vitro and in vivo studies have widely confirmed numerous pharmacological properties of moringa (Konmy et al., 2016). It exhibited curative properties such as; immune-boosting (Miyachi et al., 2004), antioxidant (Singh et al., 2009), antiinammatory, anti-diarrheal (Kesharwani et al., 2014) and antiparasitic (Hegazi et al., 2018; Kandil et al., 2018; Aboelsoued et al., 2019).

Thyme (Thymus vulgaris, T. vulgaris), belonging to the Lamiacea family, is an aromatic native herb of the Mediterranean region. This plant possesses various beneficial effects such as: antibacterial (Dorman and Deans, 2000) anticoccidial (Jamroz et al., 2003), anthelmintic (Rasooli et al., 2006) and antifungal properties (Shen et al., 2016) as it contains many compounds with therapeutic potentials like flavonoids, thymol, eugenol, carvacrol, saponins and phenols (Amarowicz et al., 2008).

The emergence of parasites that are resistant to current chemotherapies highlights the importance of plants as novel antiparasitic agents. So, the present study was designed to investigate the therapeutic effect of $M$. oleifera and T. vulgaris oils on hepatic coccidiosis in experimentally infected rabbits. Also, to detect immunomodulatory effect of the two oils.

\section{MATERIAL AND METHODS}

\section{Ethical approval}

Rabbits were housed in good conditions in the animal house of the National Research Centre (NRC), Egypt, in accordance with the ethical standards. The study protocol was approved by the Medical Research Ethics Committee of NRC, Egypt, No: 18-118.

\section{Parasite}

Collection of $E$. stiedae sporulated oocysts: The oocysts of $E$. stiedae were collected from gall bladders and necrotic hepatic lesions of naturally infected rabbits. The livers and gall bladders were removed, minced and digested in $0.25 \%$ trypsin in normal saline. Then, the digested materials were sieved and washed several times by centrifugation at $2000 \mathrm{rpm}$ for 10 minutes/ each. Oocysts were counted as described by Ryley et al. (1976) and identified according to Levine (1985). The oocysts were allowed to sporulate by incubation for 3 days in $2.5 \%$ potassium dichromate solution at $26^{\circ} \mathrm{C}$. Then, the sporulated oocysts were kept at $4^{\circ} \mathrm{C}$ until use in experimental infection and antigen preparation.

\section{Plant oils}

T. vulgaris oil was purchased from El Huawag Company, Egypt. M. oleifera seed oil was obtained from Moringa Production Unit, NRC, Egypt. Oils were emulsified with water and presented to rabbits by gastric tubes, $1 \mathrm{~h}$ before meals, for 5 consecutive days starting from the 16 th day post infection (PI) in a dose of $500 \mathrm{mg} / \mathrm{kg}$ body weight for thyme oil (Abdel-Aziem et $a l .$, 2014) and $200 \mathrm{mg} / \mathrm{kg}$ body weight for moringa oil (Khalifa et al., 2016).

\section{Experimental infection}

In this study, twenty-four New Zealand rabbits (5 weeks old and about $1.5 \mathrm{~kg}$ body weight) were used. They were reared in 
metal wire floored cages and fecal samples from all animals were examined daily for 2 weeks to ensure that animals were coccidian free. Rabbits were divided into 4 groups each one contained 6 rabbits. The first group was healthy rabbits, the $2^{\text {nd }}$ group was experimentally infected with 50000 sporulated oocysts (Abu El Ezz et al., 2012), the $3^{\text {rd }}$ group was infected and treated with moringa oil and the last group was infected and treated with thyme oil. All rabbits were examined for 7 weeks. At the end of observation period, all rabbits were sacrificed.

\section{Fecal analysis and oocysts count}

Fresh fecal samples were collected daily from experimentally infected rabbits into sterile containers from the 14th day PI till the end of the experiment to determine the number of E. stiedae oocysts per gram using the McMaster counting chamber (Long et al., 1976).

\section{Liver lesion scores}

Liver focal lesions were scored for severity of hepatic coccidiosis and the percentage of protection against lesions were performed according to Abdel Megeed \& Abu El Ezz (2005).

\section{Serological Studies}

Collection of rabbit Sera: Blood samples were collected twice a week from each rabbit in each group from zero day till the $7^{\text {th }}$ week PI., placed in plain centrifuge tubes and sera were separated and stored at $-20^{\circ} \mathrm{C}$ for further work.

Preparation of Antigen: E. stiedae oocyst antigen was prepared as described by Mousa et al. (1996) and the protein content of antigen was determined according to Lowry et al. (1951). The antigen was aliquoted and stored at $-20^{\circ} \mathrm{C}$ until use.

\section{Enzyme Linked Immunosorbent Assay} (ELISA): The immunomodulatory effect of moringa and thyme oils was evaluated through the detection of antibodies level by ELISA according to Santiago et al. (1986). The optimum antigen concentrations, sera and conjugate dilutions were determined by checkerboard titration. The absorbance was read by spectrophotometer at $405 \mathrm{~nm}$ and the cut off value of optical density (OD) was calculated according to Hillyer et al. (1992).

\section{Statistical Analysis}

Data of oocysts count and IgG antibody response were analyzed for the means and standard deviations. Significance of the results was evaluated using Analysis of variance (ANOVA) and Duncan using Statistical Package for Social Science (SPSS) computer program (2015).

\section{RESULTS}

\section{Oocysts count}

The first observation of $E$. stiedae oocysts in feces was observed in the $16^{\text {th }}$ day PI (prepatent period was 16 days). Overall, there was a gradual reduction in the number of oocysts in the infected non-treated rabbits from the day $25 \mathrm{PI}$ and continued till no oocysts were found by the day 46 PI. While, treatment of rabbits with moringa and thyme oils with the doses: $200 \mathrm{mg} / \mathrm{kg}$ and $500 \mathrm{mg} / \mathrm{kg}$, respectively, stated to reduce oocysts shedding at $21^{\text {st }}$ and $22^{\text {nd }}$ day PI, respectively. There was a highly significant reduction in oocyst shedding $(\mathrm{P}<0.001$ and $P<0.05)$ in the infected moringa and thyme oils treated rabbits than the infected nontreated ones in almost all days PI. The effect of moringa and thyme oils on oocyst shedding was statistically the same in almost days although, thyme oil was more potent and stopped oocysts shedding earlier at the day 34 compared with moringa oil at the day 41 (Table 1). During the examination of feces of the moringa and thyme oils treated rabbits, deformed oocysts were observed after the peak of oocysts count at the $24^{\text {th }}$ day PI $\left(9^{\text {th }}\right.$ day post treatment) for moringa oil and at the $25^{\text {th }}$ day PI (10 $10^{\text {th }}$ day post treatment) for thyme oil treated rabbits, respectively (Fig. 1). 
Table 1. The number of oocysts in infected treated and non-treated rabbits at different days post infection

\begin{tabular}{|c|c|c|c|c|c|}
\hline $\begin{array}{l}\text { Days Post } \\
\text { Infection }\end{array}$ & $\begin{array}{l}\text { Rabbit } \\
\text { Groups }\end{array}$ & $\begin{array}{l}\text { Infected, } \\
\text { Non-Treated }\end{array}$ & $\begin{array}{l}\text { Infected, Treated } \\
\text { with Moringa Oil }\end{array}$ & $\begin{array}{l}\text { Infected, Treated } \\
\text { with Thyme Oil }\end{array}$ & F- Value \\
\hline Day 1 & 14 & $0 \pm 0$ & $0 \pm 0$ & $0 \pm 0$ & - \\
\hline Day 1 & 15 & $0 \pm 0$ & $0 \pm 0$ & $0 \pm 0$ & - \\
\hline Day 1 & 16 & $22050 \pm 1450$ & $23200 \pm 900$ & $22400 \pm 1400$ & $0.64^{\mathrm{NS}}$ \\
\hline Day 1 & 17 & $25150 \pm 350^{\mathrm{b}}$ & $25850 \pm 150^{\mathrm{a}}$ & $25900 \pm 300^{\mathrm{a}}$ & $6.73^{*}$ \\
\hline Day 1 & 18 & $25650 \pm 50$ & $25750 \pm 50$ & $25700 \pm 200$ & $0.5^{\mathrm{NS}}$ \\
\hline Day 1 & 19 & $33500 \pm 1500^{\mathrm{a}}$ & $26750 \pm 1150^{\mathrm{b}}$ & $25750 \pm 250^{\mathrm{b}}$ & $44.0^{* * * *}$ \\
\hline Day 2 & 20 & $49000 \pm 1000^{\mathrm{a}}$ & $26250 \pm 250^{\mathrm{b}}$ & $25600 \pm 400^{\mathrm{b}}$ & $1307.42^{\text {*** }}$ \\
\hline Day 2 & 21 & $84750 \pm 5250^{\mathrm{a}}$ & $25800 \pm 300^{\mathrm{b}}$ & $26250 \pm 250^{\mathrm{b}}$ & $373.3^{* * * *}$ \\
\hline Day 2 & 22 & $132500 \pm 12500^{\mathrm{a}}$ & $22000 \pm 2000^{\mathrm{b}}$ & $21500 \pm 1500^{\mathrm{b}}$ & $226.45^{\text {*** }}$ \\
\hline Day 2 & 23 & $298500 \pm 31500^{a}$ & $21000 \pm 1000^{\mathrm{b}}$ & $19000 \pm 2000^{\mathrm{b}}$ & $233.34^{* * *}$ \\
\hline Day 2 & 24 & $291900 \pm 26100^{\mathrm{a}}$ & $16000 \pm 4000^{\mathrm{b}}$ & $13500 \pm 1500^{\mathrm{b}}$ & $329.47^{\text {**** }}$ \\
\hline Day 2 & 25 & $130000 \pm 4500^{\mathrm{a}}$ & $13000 \pm 3000^{\mathrm{b}}$ & $7000 \pm 1000^{\mathrm{b}}$ & $1430.8^{* * *}$ \\
\hline Day 2 & 26 & $126900 \pm 4600^{\mathrm{a}}$ & $12000 \pm 2000^{\mathrm{b}}$ & $4500 \pm 500^{c}$ & $1667.1^{\text {**** }}$ \\
\hline Day 2 & 27 & $124000 \pm 4000^{a}$ & $8000 \pm 2000^{\mathrm{b}}$ & $3000 \pm 0^{\mathrm{b}}$ & $2109.2^{* * *}$ \\
\hline Day 2 & 28 & $112750 \pm 2750^{\mathrm{a}}$ & $5500 \pm 500^{\mathrm{b}}$ & $1900 \pm 100^{c}$ & $4564.4^{* * *}$ \\
\hline Day 2 & 29 & $105600 \pm 8400^{\mathrm{a}}$ & $4500 \pm 500^{\mathrm{b}}$ & $1350 \pm 150^{b}$ & $446.8^{* * *}$ \\
\hline Day 3 & 30 & $101400 \pm 10900^{\mathrm{a}}$ & $2850 \pm 550^{\mathrm{b}}$ & $550 \pm 50^{\mathrm{b}}$ & $250.4^{* * * *}$ \\
\hline Day 3 & 31 & $95850 \pm 9650^{\mathrm{a}}$ & $2350 \pm 50^{\mathrm{b}}$ & $300 \pm 0^{\mathrm{b}}$ & $287.9^{* * * *}$ \\
\hline Day 3 & 32 & $90950 \pm 5950^{a}$ & $1300 \pm 300^{\mathrm{b}}$ & $100 \pm 0^{\mathrm{b}}$ & $688.6^{* * *}$ \\
\hline Day 3 & 33 & $79000 \pm 13500^{\mathrm{a}}$ & $1150 \pm 150^{\mathrm{b}}$ & $50 \pm 0^{\mathrm{b}}$ & $101.2^{* * *}$ \\
\hline Day 3 & 34 & $76100 \pm 15900^{\mathrm{a}}$ & $900 \pm 100^{\mathrm{b}}$ & $0 \pm 0^{\mathrm{b}}$ & $67.9^{* * * *}$ \\
\hline Day 3 & 35 & $73000 \pm 17000^{a}$ & $600 \pm 0^{\mathrm{b}}$ & $0 \pm 0^{\mathrm{b}}$ & $54.87^{* * * *}$ \\
\hline Day 3 & 36 & $70150 \pm 15050^{\mathrm{a}}$ & $400 \pm 100^{b}$ & $0 \pm 0^{\mathrm{b}}$ & $64.81^{* * * *}$ \\
\hline Day 3 & 37 & $65250 \pm 15050^{\mathrm{a}}$ & $150 \pm 50^{\mathrm{b}}$ & $0 \pm 0^{\mathrm{b}}$ & $56.3^{* * *}$ \\
\hline Day 3 & 38 & $49650 \pm 19150^{\mathrm{a}}$ & $100 \pm 0^{\mathrm{b}}$ & $0 \pm 0^{\mathrm{b}}$ & $20.13^{* *}$ \\
\hline Day 3 & 39 & $42800 \pm 17500^{\mathrm{a}}$ & $50 \pm 0^{\mathrm{b}}$ & $0 \pm 0^{\mathrm{b}}$ & $17.9^{* *}$ \\
\hline Day 4 & 40 & $37500 \pm 17500^{\mathrm{a}}$ & $33 \pm 14^{\mathrm{b}}$ & $0 \pm 0^{\mathrm{b}}$ & $13.76^{\text {** }}$ \\
\hline Day 4 & 41 & $25350 \pm 9650^{\mathrm{a}}$ & $0 \pm 0^{\mathrm{b}}$ & $0 \pm 0^{\mathrm{b}}$ & $20.7^{\text {** }}$ \\
\hline Day 4 & 42 & $16500 \pm 7500^{\mathrm{a}}$ & $0 \pm 0^{\mathrm{b}}$ & $0 \pm 0^{\mathrm{b}}$ & $14.52^{* * *}$ \\
\hline Day 4 & 43 & $12000 \pm 3000^{\mathrm{a}}$ & $0 \pm 0^{\mathrm{b}}$ & $0 \pm 0^{\mathrm{b}}$ & 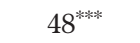 \\
\hline Day 4 & 44 & $5500 \pm 4500$ & $0 \pm 0$ & $0 \pm 0$ & $4.48^{\mathrm{NS}}$ \\
\hline Day 4 & 45 & $667 \pm 289^{\mathrm{a}}$ & $0 \pm 0^{\mathrm{b}}$ & $0 \pm 0^{\mathrm{b}}$ & $16^{\text {** }}$ \\
\hline Day 4 & 46 & $0 \pm 0$ & $0 \pm 0$ & $0 \pm 0$ & - \\
\hline
\end{tabular}

Data are expressed as Mean \pm SD. Means that are followed by different letters indicated significance. N.S. Non-significant, ${ }^{*}$ Significant differences at $P<0.05,{ }^{* *} P<0.01,{ }^{* * * *} P<0.001$.

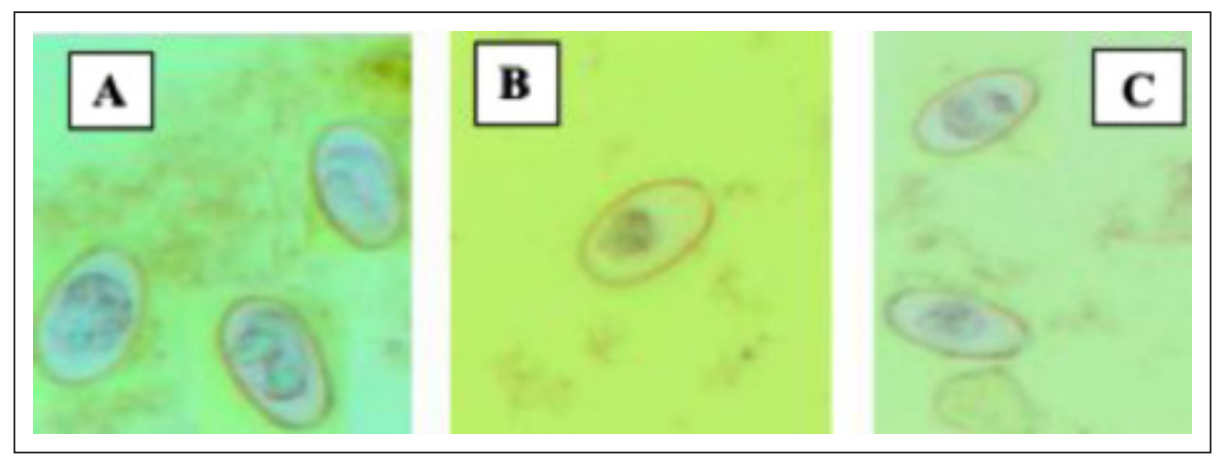

Figure 1. Sporulated oocysts of Eimeria stiedae isolated from infected non-treated rabbits (X400) (A). Deformed Eimeria stiedae oocysts observed in moringa (B) and thyme (C) oils treated rabbit feces (X400). 


\section{Macroscopic Lesions}

Examined livers of healthy non-infected rabbits showed normal structure of liver tissue (Fig. 2A). Infected non-treated rabbit livers were extensively enlarged and pale in color. Many scattered yellowish-white nodules of variable sizes containing creamy fluid packed with oocysts were observed on liver surface tissue and the gall bladder was enlarged and greatly distended with creamy yellowish fluid (Fig. 2B). Livers of infected and moringa and thyme oils treated rabbits showed enhancement than livers of infected non-treated rabbits, whereas, thyme oil treated rabbits showed more enhancement in liver's morphology (Fig. 2C) than moringa oil treated rabbits (Fig. 2D).

\section{Lesion Score}

Lesion score was used as a parameter of infection severity (Fig. 2). It was found that mean focal lesions score in liver was 4 in the infected non-treated rabbits, 1.8 in the infected moringa oil treated rabbits and 1 in the infected thyme oil treated rabbits. Non-infected rabbits exhibited no lesions (Table 2). Rabbits infected and treated with moringa and thyme oils showed high level of protection (55 and 75\%, respectively) against lesion score compared to the protection percentage of infected non treated rabbits (0\%) (Table 2).

\section{Detection the level of antibodies in treated and non-treated rabbits:}

As shown in Figure 3, using E. stiedae oocyst antigen in ELISA, IgG antibody response in experimentally infected non treated rabbits started from $7^{\text {th }}$ day PI and reached its maximum level at third week, then declined slightly till the fourth week before take plateau shape till the end of

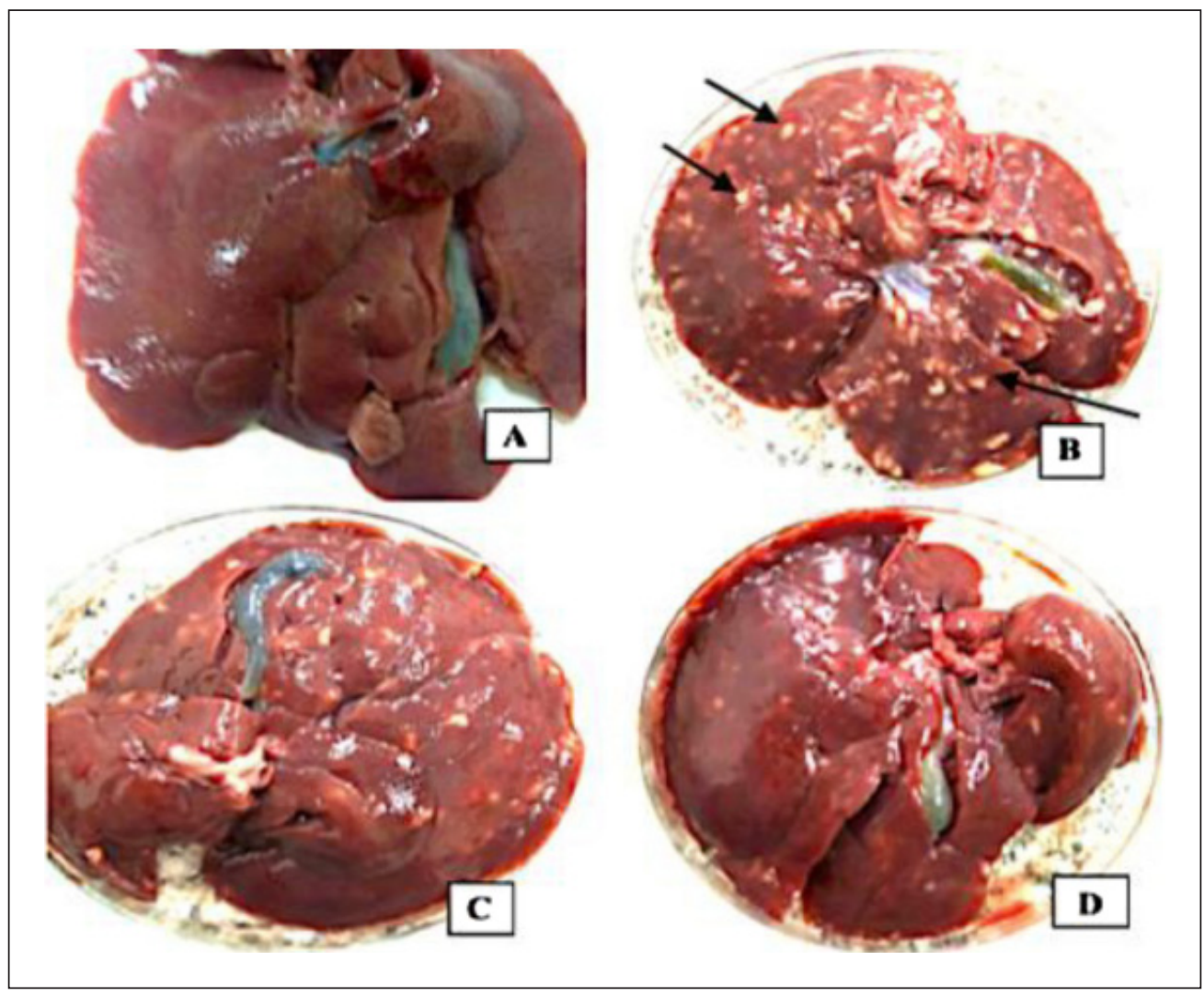

Figure 2. Examined livers of healthy rabbits (A), Irregular yellowish-white nodules of variable sizes (some showed by arrows) on the surface tissue of liver of domestic rabbits infected with hepatic coccidiosis (B). Livers of moringa and thyme oils treated rabbits (C and D, respectively) showing enhancement than livers of infected non-treated rabbits. 
Table 2. Liver lesion score of healthy and infected rabbits

\begin{tabular}{|c|c|c|}
\hline Group Parameter & Mean lesion score & Percentage of protection \\
\hline Non-infected rabbits & 0 & $100 \%$ \\
\hline Infected non treated rabbits & 4 & $0 \%$ \\
\hline Infected moringa oil treated rabbits & 1.8 & $55 \%$ \\
\hline Infected thyme oil treated rabbits & 1 & $75 \%$ \\
\hline
\end{tabular}

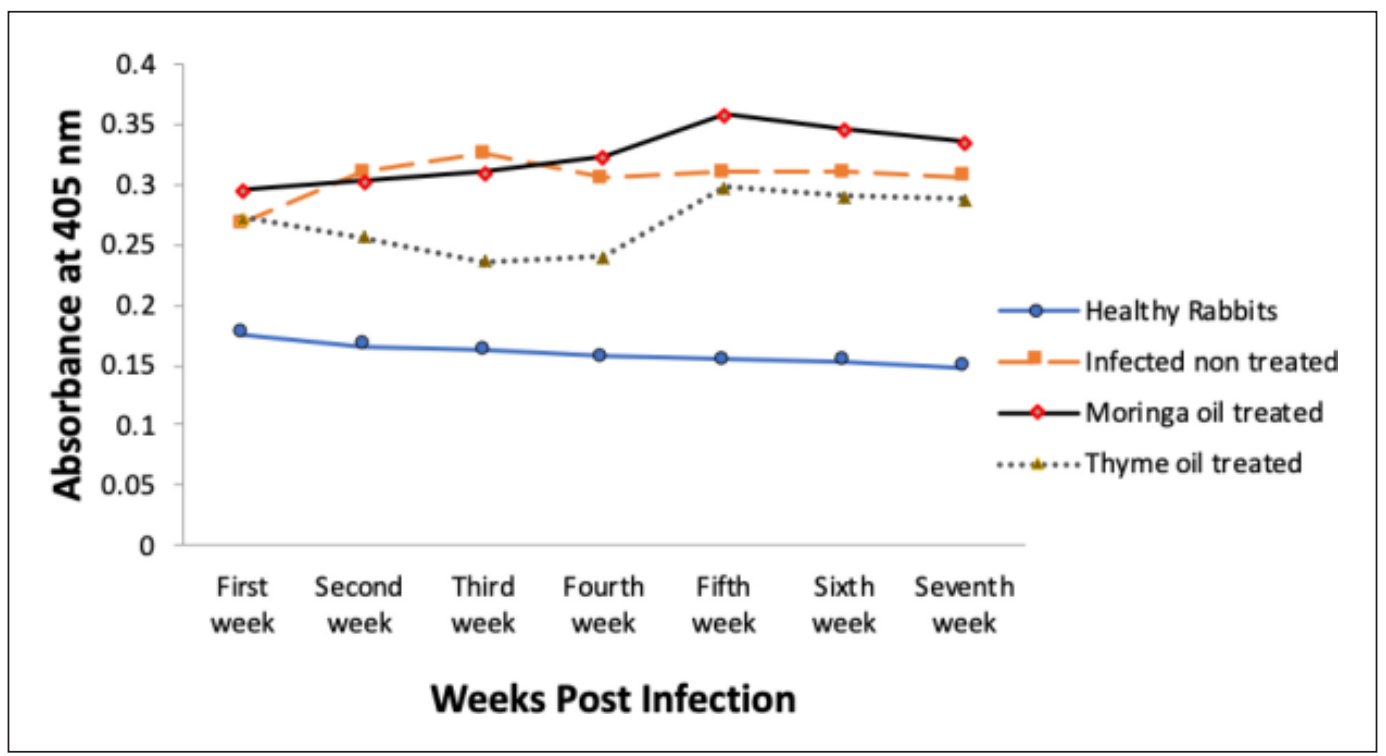

Figure 3. IgG antibody response in experimentally infected, treated and non-treated rabbits.

experiment. In the two treated groups the level of antibodies increased after treatment with moringa and thyme oils at third week PI (first week post treatment) till reached their maximum level at fifth week PI. Then declined slightly till the end of the experiment.

Statistically, starting from the $3^{\text {rd }}$ week PI, which is considered the first week post treatment, till the end of the $4^{\text {th }}$ week, thyme oil showed a significant decrease $(P<0.05)$ than moringa oil treated and the infected non treated ones which were similar statistically. At the $5^{\text {th }}$ week PI, IgG antibodies response increased significantly $(P<0.05)$ in moringa oil treated rabbits than the other two infected groups. At the same week, IgG antibodies response in thyme oil treated rabbits didn't differ significantly from those of the infected non treated ones. At the $6^{\text {th }}$ and $7^{\text {th }}$ weeks
PI, IgG antibodies response showed a significant increase $(P<0.05)$ in moringa oil treated rabbits and a significant decrease $(P<0.05)$ in thyme oil treated rabbits compared with the infected non treated ones.

\section{DISCUSSION}

Rabbit hepatic coccidiosis is one of the most important diseases affecting rabbit production industry. In the current study, parasitological examination of experimentally infected rabbit feces revealed that the prepatent period of $E$. stiedae infection was 16 days. Similar results were observed by Abdel Megeed \& Abu El Ezz (2005) and Abu El Ezz et al. (2012). There was a gradual 
reduction in the number of oocysts in the infected non-treated rabbits from the day $25 \mathrm{PI}$ and continued till no oocysts were found by the day 46 PI. Comparable results were detected by Abu El Ezz et al. (2012) in experimentally infected rabbits with $E$. stiedae. In the current experiment, after treatment of infected rabbits with moringa $(200 \mathrm{mg} / \mathrm{kg}$ ) and thyme (500 mg/kg) oils, the number of shedding oocysts was decreased starting from the $21^{\text {st }}$ and $22^{\text {nd }}$ days PI, respectively, then completely disappeared at $34^{\text {th }}$ day for thyme which the most potent followed by moringa, where, the disappearance occurred at $41^{\text {st }}$ day PI. Moringa and thyme oils not only affect the number of shedding oocysts but also the deformed oocysts were observed during microscopic examination. This effect of moringa and thyme oils might be due to the potent therapeutic compounds found in these plants. Studies had shown that $M$. oleifera contained many bioactive compounds including vitamins, essential amino acids, polyphenols, flavonoids and phenolic acids (Leone et al., 2015). Mature moringa seeds exhibited curative effects as they contain cysteine, benzyl isothiocynate (Katre et al., 2008). In addition, the low density of plant oil and its rapid diffusion through cell membranes could enhance the targeting of active components within the oil against parasites (Anthony et al., 2005). Also, Ola-Fadunsin \& Ademola (2013) reported that Moringa Oleifera were used to treatment broiler chickens naturally infected with Eimeria species. El Banna et $a l$. (2016) confirmed the anticoccidial activity of $M$. Oleifera. Furthermore, thyme contains many compounds that had therapeutic potentials like flavonoids, thymol, eugenol, carvacrol, saponins and phenols (Amarowicz et $a l ., 2008)$. Thyme extract containing thymol caused destruction of oocysts of E. tenella (Abbas et al., 2012). T. vulgaris was able to destroy parasites, including oocysts and sporozoites (Muthamilselvan et al., 2016). Essential oils derived from $T$. vulgaris and other plants showed inhibition of Eimeria species at different developmental stages (Muthamilselvan et al., 2016).
Also, Evans et al. (2001) reported a reduction of coccidia oocyst excretion in chicks fed the diets mixed with clove, thyme, lemon and peppermint essential oil mixture. In this study, the diference between the anticoccidial effect of the two oils might be due to the differences in active components of each oil which might act in a different way.

In the current study, livers of infected non-treated rabbits were extensively enlarged and pale in color with crowded yellowish-white nodules packed with oocysts of variable sizes containing creamy fluid. The gall bladders were enlarged and greatly distended with creamy yellowish fluid. These results matched with those observed by Cam et al. (2008), Abu-Akkada et al. (2010) and Abu El Ezz et al. (2012). These characteristic lesions of rabbit coccidiosis might be due to fibrosis and intense biliary hyperplasia. The livers of infected rabbits treated with thyme oil showed more enhancement in morphology than moringa oil treated livers and this might be due to that the thyme extract has an inhibitory effect on lipid peroxidation, which could decrease the strength of inflammatory response (Bozin et al., 2006). In addition, this result might be due to the ability of thyme oil to eliminate infection in less time than the moringa oil, which helped to keep the liver in a better condition. Also, lesion scores recorded from livers of experimentally infected rabbits that were treated with moringa and thyme oils could be considered as a strong indication of the potent effect of these oils with the superiority of thyme oil.

In the present study, IgG antibody response in experimentally infected nontreated rabbits started from $7^{\text {th }}$ day PI and reached its maximum level at third week, then declined slightly before taking plateau shape and still in high level till the end of the experiment. These results were comparable to those obtained by Constantinoiu et al. (2007) and Abu El Ezz et al. (2012). IgG antibody response in infected rabbits treated with moringa oil increased after the third week PI (first week post treatment) and reached its maximum level at the fifth week and still in high level till the end of the 
experiment. Similar immunomodulatory effect of $M$. oleifera was reported by Miyachi et al. (2004) and Nfambi et al. (2015). The current result was not consistent with El Shanawany et al. (2019) who reported that $M$. oleifera leaves aqueous extract caused reduction in the level of IgG in Fasciola gigantica infected sheep. This difference in immune response might be due to that they used moringa leaves extract while, in current study, oil extract was used in addition to difference in used host and parasite. In the current study, rabbits treated with thyme oil showed an elevation in IgG antibody response from the third week PI (first week post treatment) and reached its peak at the fifth week PI then declined till the end of experiment and still in level less than IgG in moringa treated rabbits. This may be due to the rapid disappearance of the infection, resulting in a decrease in the level of antibodies or inability of the thyme to memorize the immune system of infected treated rabbits. In a previous study, the supplementation of thyme extract in drinking water did not improve the immune status in broiler chickens (Abdulkarimi, 2011) and this confirmed our results. In a previous study, the success of volatile plant oils as an alternative treatment for parasites depended on their anti-parasitic effect and also their improvement of host immune system (Anthony et al., 2005). In the current study, although moringa oil proved immunomodulatory effect for rabbit immune system, thyme oil proved more anticoccidial effect and eliminated the infection in time less than moringa oil. Therefore, thyme oil needs further research to clarify this phenomenon in order to be widely used in the treatment of coccidiosis.

\section{CONCLUSION}

This study proved that both $M$. oleifera and T. vulgaris oils had an anti-coccidial effect with T. vulgaris oil superiority. So, T. vulgaris oil could be useful as an alternative product for the control of rabbit coccidiosis.

\section{Authors' contributions}

All authors prepared the research plan and designed experiments. NMTA contributed to isolation of oocysts, experimental infection, counting of oocysts, examination of livers and lesion score determination. DA shared in isolation of oocysts, experimental infection, counting of oocysts, antigen preparation, ELISA, data interpretation and statistical analysis. SEH contributed to dose preparation, antigen preparation, ELISA and data interpretation. KNA shared in isolation of oocysts, experimental infection, antigen preparation, ELISA and laboratory work analysis. TME contributed to sample collection. All authors shared in manuscript preparation and approved the final version of the manuscript.

\section{Declaration of conflicting interests}

The author(s) declared no potential conflicts of interest with respect to the research, authorship, and/or publication of this article.

\section{REFERENCES}

Abbas, R.Z., Colwell, D.D. \& Gilleard, J. (2012). Botanicals: an alternative approach for the control of avian coccidiosis. World's Poultry Science Journal 68: 203-215.

Abdel Megeed, K.N. \& Abu El Ezz, N.M.T. (2005). Control of Hepatic coccidiosis in rabbits using Calendula micrantha officinalis and Peganum harmala extracts. Egyptian Jourmal of Veterinary Science 39: 34-45.

Abdel-Aziem, S.H., Hassan, A.M., ElDenshary, E.M., Hamzawy, M.A., Mannaa, F.A. \& Abdel-Wahhab, M.A. (2014): Ameliorative effects of thyme and calendula extracts alone or in combination against aflatoxins-induced oxidative stress and genotoxicity in rat liver. Cytotechnolog 66(3): 457-470.

Abdulkarimi, R. (2011). Immune response of broiler chickens supplemented with Thyme extract (Thymus vulgaris) in drinking water. Annals of Biological Research 2(6): 208-212. 
Aboelsoued, D., Toaleb, N.I., Abdel Megeed, K.N., Hassan, S.E. \& Ibrahim, S. (2019): Cellular immune response and scanning electron microscopy in the evaluation of Moringa leaves aqueous extract effect on Cryptosporidium parvum in buffalo intestinal tissue explants. Journal of Parasitic Diseases 43(3): 393-401.

Abu-Akkada, S.S., Oda, S.S. \& Ashmawy, K.I. (2010). Garlic and hepatic coccidiosis: prophylaxis or treatment? Tropical Animal Health and Production 42: 13371343.

Abu El Ezz, N.M.T. (2005). Comparative efficacy of Nigella sativa seeds and Diclazuril on coccidiosis in chickens. Journal of Egyptian Veterinary Medical Association 65: 137-147.

Abu El Ezz, N.M.T., Abdel Megeed, K.N., Mahdy, O.A. \& Hassan, S.E. (2012). ELISA assessment in the diagnosis of hepatic coccidiosis in experimentally infected rabbits. Global Veterinaria 9(5): 517-523.

Amarowicz, R., Zegarska, Z., Rafałowski, R., Pegg, R.B., Karamac, M. \& Kosin, A. (2008). Antioxidant activity and free radical-scavenging capacity of ethanolic extracts of thyme, oregano, and marjoram. European Journal of Lipid Science and Technology 110(1): 1-7.

Anthony, J.P., Fyfe, L. \& Smith, H. (2005). Plant active components - a resource for antiparasitic agents? Trends Parasitology 21(10): 462-468.

Bozin, B., Mimica-Dukic, N., Simin, N. \& Anackov, G. (2006). Characterization of the volatile composition of essential oils of some lamiaceae spices and the antimicrobial and antioxidant activities of the entire oils. Journal of Agricultural and Food Chemistry 54(5): 1822-1828.

Cam, Y., Alasever, A., Eraslan, G., Kibar, M., Atalay, O., Beyaz, L., Inci, A. \& Liman, B.C. (2008). Eimeria stiedae: Experimental infection in rabbits and the effect of treatment with toltrazuril and ivermectin. Experimental Parasitology 119: 164171.
Chacko, N., George, A.J., Gleeja, V.L. \& Vijayan, N. (2017). Retrospective study on the incidence of coccidiosis in rabbits and goats. Indian Veterinary Journal 94(11): 30-32.

Chowdhury, A.A. \& Fraser, G.C. (2008). Coccidia (Eimeria spp.) of domestic rabbits in New South Wales. Australian Veterinary Journal 86: 365-366.

Constantinoiu, C.C., Molloy, J.B., Jorgensen, W.K. \& Coleman, G.T. (2007): Development and validation of an ELISA for detecting antibodies to Eimeria tenella in chickens. Veterinary Parasitology $\mathbf{1 5 0}$ : 306-313.

Dalloul, R.A. \& Lillehoj, H.S. (2005). Recent advances in immunomodulation and vaccination strategies against coccidiosis. Avian Diseases 49: 1-8.

Dorman, H.G.D. \& Deans, S.G. (2000): Antimicrobial Plants: Antibacterial Activity of Plant, Applied Microbiology 88(2): 308-316.

El Banna, H.A., Atef, M. \& Nabil, G. (2016). Anti-coccidial activity of Moringa Oleifera plant. Animal Veterinary Sciences 4(2): 19-25.

El-Shahawi, G.A., El-Fayomi, H.M. \& AbdelHaleem, H.M. (2012). Coccidiosis of domestic rabbit (Oryctolagus cuniculus) in Egypt: Light microscopic study. Parasitology Research 110(1): 251-258.

El Shanawany, E.E., Fouad, E.A., Keshta, H.G., Hassan, S.E., Hegazi, A.G. \& AbdelRahman, E.H. (2019): Immunomodulatory effects of Moringa oleifera leaves aqueous extract in sheep naturally co-infected with Fasciola gigantica and Clostridium novyi. Journal of Parasitic Diseases 43(4): 583-591.

Evans, J.W., Plunkett, M. \& Banfield, M. (2001). Effect of an essential oil blend on coccidiosis in broiler chicks. Poultry Science 80: 258.

FAO (Food and Agriculture Organization of the United Nations) (2020). Available from: http://www.fao.org/faostat/en/ \#data/QL/visualize [accessed 2020 June 29]. 
Hegazi, A.G., Abdel Megeed, K.N., Hassan, S.E., Abdelaziz, M.M., Toaleb, N.I., El Shanawany, E.E. \& Aboelsoued, D. (2018). Comparative ovicidal activity of Moringa oleifera leaf extracts on Fasciola gigantica eggs. Veterinary World 11(2): 215-220.

Hillyer, G.M., Soler De Galanes, M., Rodriguez-Perez, J., Bjorland, J., De Lagrava, M.S., Guzman, S.R. \& Bryan, R.T. (1992). Use of the falcon assay screening test enzyme-linked immunosorbent assay (FASTELISA) and the enzyme-linked immunoelectrotransfer blot (EITB) to determine the prevalence of human fascioliasis in the Bolivian Altiplano. The American Jourmal of Tropical Medicine and Hygiene 46: 603-609.

Jamroz, D., Orda, J., Kamel, C., Wiliczkiewicz, A., Wertelecki, T. \& Skorupinska, J. (2003). The influence of phytogenic extracts on performance, nutrient digestibility, carcass characteristics, and microbial status in broiler chickens. Journal of Animal feed and Science 12: 583-596.

Kandil, O.M., Hassan, N.M.F., Sedky, D., Ata, E.B., Nassar, S.A., Shalaby, H.A., Nanev, V., Tsocheva-Gaytandzhieva, N. \& Gabrashanska, M. (2018): Anthelmintic efficacy of Moringa oleifera seed methanolic extract against Fasciola hepatica. Journal of Parasitic Diseases 42(3): 391-401.

Karaer, Z. (2001). Evciltavsanlarda coccidiosis. In: Dincer, S. (Ed.), Coccidiosis. Türkiye Parazitoloji DerneğiYayın, no. 17. META Basım, Bornova-Izmir, pp. 269-278.

Katre, U.V., Suresh, C.G., Khan, M.I. \& Gaikwad, S.M. (2008): Structure-activity relationship of a hemagglutinin from Moringa oleifera seeds. International Journal of Biological Macromolecules 42: 203-207.

Kesharwani, S., Prasad, P., Roy, A. \& Sahu, R.K. (2014). An overview on phytochemistry and pharmacological explorations of Moringa oleifera. Journal of Pharmaceutical and BioSciences 2(1): 34-41.
Khalifa, W.H., Ibrahim, F.M., El Makawy, A.I., Sharaf, H.A., Khalil, W.K.B. \& Maghraby, N.A. (2016). Safety and fertility enhancing role of Moringa oleifera leaves aqueous extract in new zealand rabbit bucks. International Journal of Pharmacology 6(1): 156-168.

Kheirabadi, K.P., Katadj, J.K., Bahadoran, S., da Silva, J.A.T., Samani, A.D. \& Bashi, M.C. (2014). Comparison of the anticoccidial effect of granulated extract of Artemisia sieberi with monensin in experimental coccidiosis in broiler chickens. Experimental Parasitology 141: 129-133.

Konmy, B.B.S., Olounladé, P.A., Allou, S.D., Azando, E.V.B. \& Hounzangbé-Adoté, M.S. (2016). A review on phytochemistry and pharmacology of Moringa oleifera leaves (Moringaceae). Journal of Pharmacognosy Phytochemistry 5(5): 325-330.

Leone, A., Spada, A., Battezzati, A., Schiraldi, A., Aristil, J. \& Bertoli, S. (2015). Cultivation, genetic, ethnopharmacology, phytochemistry and pharmacology of Moringa oleifera leaves: an overview. International Journal of Molecular Science 16: 12791-12835.

Levine, N.D. (1985). Veterinary protozoology. Iowa State University Press, Ames.

Long, P.L., Joyner, L.P., Millered, B.J. \& Norton, C.C. (1976). A guide to laboratory techniques used in the study and diagnosis of avian coccidiosis. Folia Veterinaria Latina 6: 201-217.

Lowry, O.H., Rosebrough, J., Farr, A.L. \& Randall, R.J. (1951). Protein measurement with the folin phenol reagent. Journal of Biological Chemistry 193: 265-275.

Miyachi, K., Fritzler, M.J. \& Tan, E.M. (2004): Benzyl isothiocyanate inhibits excessive superoxide generation in inflammatory leukocytes: implication for prevention against inflammation-related carcinogenesis. Carcinogenesis 25: 567-575.

Mousa, W.M., Fouad, S., Saad, A. \& AbdelHakim, S. (1996). Evaluation of the different development stages of $F$. gigantica for the serodiagnosis of human fascioliasis. Egyptian Journal of Immunology 3: 63-68. 
Muthamilselvan, T., Kuo, T.F., Wu, Y.C. \& Yang, W.C. (2016). Herbal Remedies for Coccidiosis Control: A Review of Plants, Compounds, and Anticoccidial Actions. Evidence Based Complementary Alternative Medicine, 2657981, 19 pages.

Nfambi, J., Bbosa, G.S., Sembajwe, L.F., Gakunga, J. \& Kasolo, J.N. (2015). Immunomodulatory activity of methanolic leaf extract of Moringa oleifera in Wistar albino rats. Journal of Basic Clinical Physiology and Pharmacology 26(6): 603-611.

Nistor, E., Bampidis, V.A., Pãcalã, N., Pentea, M., Tozer, J. \& Prundeanu, H. (2013). Nutrient Content of Rabbit Meat as Compared to Chicken, Beef and Pork Meat. Journal of Animal Production Advances 3(4): 172-176.

Okumu, P.O., Gathumbi, P.K., Karanja, D.N., Mande, J.D., Wanyoike, M.M. \& Gachuiri, C.K. (2014). Prevalence, pathology and risk factors for coccidiosis in domestic rabbits (Oryctolagus cuniculus) in selected regions in Kenya. Veterinary Quarterly 34(4): 205-210.

Ola-Fadunsin, S.D. \& Ademola, I.O. (2013). Direct effects of Moringa oleifera Lam (Moringaceae) acetone leaf extract on broiler chickens naturally infected with Eimeria species. Tropical Animal Health and Production 45(6): 1423-8.

Oliveira, U.C., Fraga, J.S., Licois, D., Pakandl, M. \& Gruber, A. (_ ). Development of molecular assays for the identification of the 11 Eimeria species of the domestic rabbit (Oryctolagus cuniculus). Veterinary Parasitology 176(2-3): 275-280.

Rasooli, I., Rezaei, M.B. \& Allameh, A. (2006). Ultrastructural studies on antimicrobial efficacy of thyme essential oils on listeria monocytogenes. Intermational Journal of Infectious Diseases 10(4): 236-241.
Ryley, J.F., Meade, R., Hazalhurst, J. \& Robinson, T.E. (1976). Methods in coccidiosis research: separation of oocysts from feces. Parasitology 73(3): 311-326.

Santiago, N., Hillyer, G.V., Garcia-Rosa, M. \& Morales, M.H. (1986). Identification of functional Fasciola hepatica antigens in experimental infections in rabbits. International Journal of Parasitology 14: 197-206.

Shen, Q., Zhou, W., Li, H., Hu, L. \& Mo, H. (2016). ROS involves the fungicidal actions of thymol against spores of Aspergillus flavus via the Induction of nitric oxide. PLoS one 11(5): e0155647.

Singh, B.N., Singh, B.R., Singh, R.L., Prakash, D., Dhakarey, R., Upadhyay, G. \& Singh, H.B. (2009). Oxidative DNA damage protective activity, antioxidant and antiquorum sensing potentials of Moringa oleifera. Food and Chemical Toxicology 47: 1109-1116.

Sivajothi, S., Reddy, B.S. \& Rayulu, V.C. (2016). Study on impression smears of hepatic coccidiosis in rabbits. Journal of Parasitic Diseases 40(3): 906-909.

Tehrani, A.A., Yakhchali, M., Beikzadeh, B. \& Morvaridi, A. (2013). Prevalence of rabbit hepatic coccidiosis in north west of Iran. Archives of Razi Institute 68(1): 65-69.

SPSS statistics (2015). Statistical Package for Social Science, SPSS for windows Release 2015. "Standard Version, copyright, IBM Corporation".

Yin, G., Goraya, M.U., Huang, J., Suo, X., Huang, Z. \& Liu, X. (2016). Survey of coccidial infection of rabbits in Sichuan Province, Southwest China. Springer Plus 5: 870. 